\title{
Correction: Cultivating Youth Engagement: Race \& the Behavioral Effects of Critical Pedagogy
}

\section{Matthew D. Nelsen ${ }^{1}$}

Published online: 30 November 2019

(c) Springer Science+Business Media, LLC, part of Springer Nature 2019

\section{Correction to: Political Behavior https://doi.org/10.1007/s11109-019-09573-6}

The original version of this article unfortunately contains the following errors.

- In the heading "Political Participation and Civic Education", the text "these trends tend persist" should read "these trends tend to persist".

- In the heading "Pre-treatment Effects", the text "In order theorize" should read "In order to theorize".

- In Table 4, there are two incorrect signs: 0.10 should be -0.10 and 0.15 should be -0.15 . The correct Table 4 is given below.

The original article can be found online at https://doi.org/10.1007/s11109-019-09573-6.

Matthew D. Nelsen

MatthewNelsen2021@u.northwestern.edu

1 Department of Political Science, Northwestern University, Scott Hall, 601 University Place,

Evanston, IL 60208, USA 


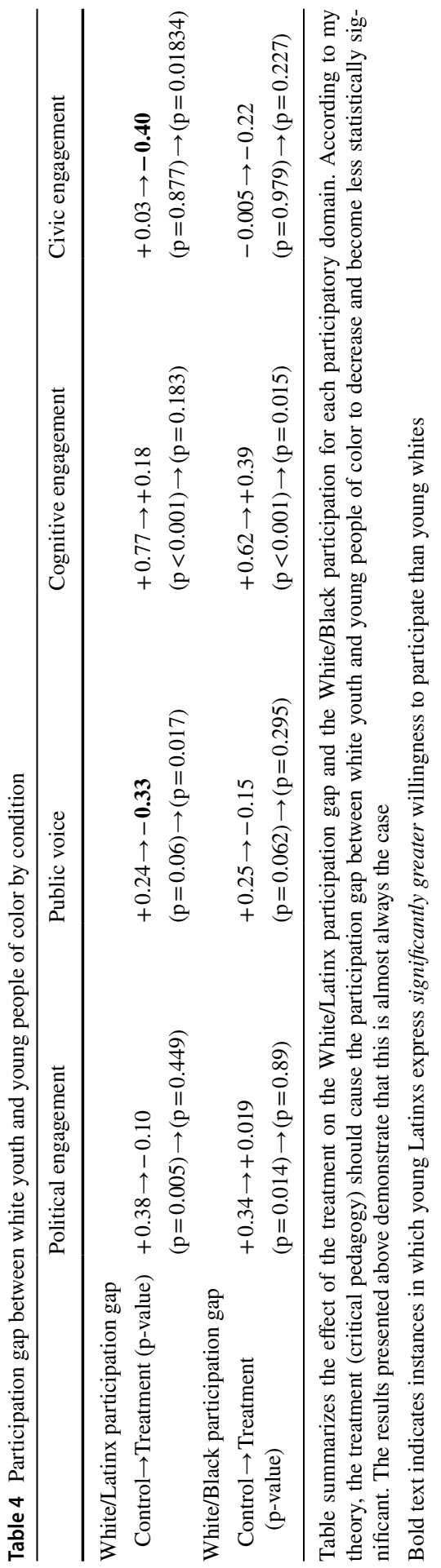


Publisher's Note Springer Nature remains neutral with regard to jurisdictional claims in published maps and institutional affiliations. 